\title{
Sensitive Heritage: Ethnographic Museums, Provenance Research, and the Potentialities of Restitutions
}

\author{
Philipp Schorch
}

\begin{abstract}
This introduction lays out this special issue, which juxtaposes articles on approaches to provenance research, conducted at German museum and university institutions, with articles on past, present and future potentialities of restitutions to originating societies in Aotearoa New Zealand, Australia and Namibia. In doing so, the issue makes the argument that provenance research and processes of restitution, and their underlying ethical and sensitive considerations, generate, rather than restrict, new knowledge. They are brimming with epistemic and ontological potentialities: for the people related to the material entities concerned, for the (anthropological) knowledge about them, and for the institutions involved. The ultimate goal pursued is the establishment and further development of provenance research and processes of restitution as ethnographic work and an integral dimension of ethnographic museums in the twenty-first century.
\end{abstract}

Key words: Sensitive heritage, ethnographic museums, provenance research, restitution, Africa/Europe/Pacific

Claims for restitution and calls for provenance research in ethnographic museums are supercharged topics at this point in time. Writing as I am in Germany, during the development of the Humboldt Forum's ambitious initiative to reinvent the rebuilt imperial Berliner Schloss (Berlin Castle) as a re-enlightening museum forum for the world (Bredekamp and Schuster 2016; Stiftung Preußischer Kulturbesitz 2015; von Bose 2016), the heat of present day debates is intense. Throughout its conceptual evolution, the Humboldt Forum has, somewhat unwittingly, brought Germany's difficult colonial past back to the attention of a transforming national commemorative culture (Thiemeyer 2016), while also attracting international scrutiny, critique and protest. ${ }^{1}$ The associated contentious debates indicate that ethnographic museums in the German-speaking world, where colonial histories have, until recently, been largely invisible in public discourses, are often lagging behind in the processes of political decolonization and critical disciplinary reflexivity that have occurred, for example, in (post-)settler nations across the Pacific. (Post-)colonial renegotiations in former European colonies, as in the Americas and the South Pacific, have, for instance, brought about dramatic changes to anthropological practices through Indigenous curatorial interventions. In such cases, museums, anthropology, and related fields have been (partly) decolonized and (incompletely) Indigenized by museum professionals who draw on Indigenous perspectives to reshape collecting, exhibiting, fieldwork and research, which are often conducted in partnership with nearby so-called source communities (Hakiwai 2014; Kreps 2003; Phillips 2013; Schorch et al. In Print; Schorch and McCarthy 2019; Stanley 2007).

Since the 1980s, countries such as Aotearoa New Zealand, Australia, Canada, and the USA have witnessed the institutional emergence and development of legal frameworks, political processes, research methods and ethical museum practices. Due to their internal (post-) colonial realities, conflicts and claims, these post-settler states have been marked by a shift in attention to the renewed centrality of museums in multicultural, (post-)colonial and globalized societies. In this context, an increasing number of museums, governmental departments, international organizations, national committees as well as Indigenous communities and institutions have been involved in processes of restitution. Crucially, the underlying debates 
around colonial injustices and loot, and the continuing relevance of sacred objects and human remains, have led to the incorporation of Indigenous epistemologies and ontologies into the formation of political positions and legal provisions. As a consequence, museums in North America and the South Pacific have generated and displayed a significant increase in the depth and extent of (anthropological) knowledge about Indigenous material entities, while developing collaborative, inclusive and culturally sensitive approaches.

At the same time, so-called ethnographic objects in European museums remain largely disconnected from the distant cultural environments of their Indigenous producers and the Indigenous sources of (anthropological) knowledge as well as the above-described innovations in museum theory and practice. Given the extent of newly emerging responsibilities and tasks, exemplified in the Humboldt Forum, one can detect a sense of overwhelming helplessness in the German museum landscape when it comes to issues of the German colonial past - often considered as distant in geographical, and short in temporal terms - which points to a deficit in the institutional implementation of systematic research processes and robust methodical approaches. This special journal issue addresses this lacuna by offering international expertise drawn from the Pacific and the African continent to speak to the German and wider European ethnographic museum sector with the dual goal of developing these insights towards their reapplication in other institutional settings, and of establishing provenance research and processes of restitution as ethnographic work.

As pointed out, ethnographic museums are increasingly discussed and contested institutions in Germany, Europe and beyond. The debate around issues such as the provenance of so-called ethnographic objects collected in colonial contexts and the restitution of illegitimately removed human remains to the descendants of the deceased are particularly intense (Aranui 2017; Fforde, Hubert and Turnbull 2004; Förster et al. 2018; Jenkins 2011; Marstine 2011; Redmond-Cooper 2015; Turnbull and Pickering 2010; Tythacott and Arvanitis 2014). ${ }^{2}$ The debate, however, often remains at the level of political opinion and lacks critical and productive interrogation. Restitution is often seen as an individual and final act, as an end in itself, which could even threaten the survival of museum collections and research. But what happens if we reconsider restitution itself as ethnographic work, or as an ethnographic method, which allows us to delve deeper into the meanings of material entities and the life of things? What can be gained, rather than lost, if we approach restitution as an integral dimension of the 'museum as process' (Silverman 2014) through which 'ethnographic objects' and human remains can be reconnected with the cultural environments of their source societies and customary sources of knowledge? In short, what is new that we can study, learn and understand through processes of restitution while writing the next chapter of the ongoing relationships between 'here' and 'there', 'us' and 'them'? ${ }^{3}$

This special issue sets out to produce answers to these key questions by considering 'heritage' not only as 'difficult' (Macdonald 2008), but as sensitive, that is, as being felt and remembered through violent histories, (re)lived through traumatic experiences, and (re)enacted through the affective relationships between people and material entities. ${ }^{4}$ Provenance research and processes of restitutions, then, require ethical museum practices and approaches that are attentive to sensitive concerns and not just knowledge production per se. Importantly, such ethical and sensitive considerations themselves generate, rather than restrict, new knowledge. That is, they are brimming with epistemic and ontological potentialities: for the people related to the material entities concerned, for the (anthropological) knowledge about them, and for the institutions involved.

This is the point where this special issue attempts to intervene. It does so by juxtaposing articles on concrete approaches to provenance research, conducted at German museum and university institutions (Gesa Grimme, Paola Ivanov and Kristin Weber-Sinn, and Andreas Winkelmann), with articles on past, present and future potentialities of restitutions to originating societies in Aotearoa New Zealand, Australia and Namibia (Amber Aranui, Jeremy Silvester and Napandulwe Shiweda, and Paul Turnbull). This issue is thus a joint effort, launched from both sides of the (post-)colonial equation, to counter the 'defensive discourses' 5 that characterize much of the responses to restitution claims by shedding light on their various potentialities for cultural life, from the past to the present and into the future (Schorch and Kahanu 2015). The 
authors do so, for example, by presenting histories of restitution movements in Aotearoa New Zealand (Aranui) and Australia (Turnbull), highlighting their significance for the achievements of Indigenous resurgence despite the many challenges and obstacles that remain. Others reveal the ongoing efficacy of power stones on contemporary communities in present-day Namibia (Silvester and Shiweda).

This special issue and the conference it is based on, has brought together people from three continents. More precisely, material entities - through their transfer, presence and restitution - have brought those people together. Far from being dead relics and static records of the past, they continue to live material lives of unforeseen potentialities, provoking human debate, contestation, conflict and, potentially, reconciliation and reciprocal knowledge production. In this vein, the issue supports the argument that facilitating, substantiating and shaping the materialized temporal juncture of histories, present realities and future (re)imaginations is what ethnographic museums should be about in the twenty-first century (Schorch et al. 2019). The authors from four countries (Aotearoa New Zealand, Australia, Germany and Namibia) and three regions (Africa, Europe and the Pacific) have substantial international expertise and experience in conducting provenance research and restitutions. They simultaneously internationalize and provincialize the 'German debate', which often lacks international perspectives and is largely, almost exclusively, focused on the capital of Berlin, as through the Humboldt Forum. The authors are thus perfectly placed to create a platform for meaningful and substantial engagements devoted to Sensitive Heritage: Ethnographic Museums, Provenance Research, and the Potentialities of Restitutions.

Received: 7 February 2020 Finally Accepted 21 February 2020

\section{Acknowledgements}

The conference on 'Sensitive Heritage: Ethnographic Museums and Material/Immaterial Restitutions' held on 11-13 December 2018 at the Grassi Museum für Völkerkunde zu Leipzig, Germany, which formed the basis of this special issue, was generously funded by the Fritz Thyssen Stiftung (Az. 30.18.0.086AA). Research informing this issue was supported through funding received from the European Union's Horizon 2020 Research and Innovation Programme through the ERC Starting Grant No. 803302 'Indigeneities in the $21^{\text {st }}$ Century'.

\section{Notes}

1 See especially 'No Humboldt 21!', www. no-humboldt21.del, accessed 18 June 2019.

2 I opt for 'restitution' rather than 'repatriation' in this introduction to this special issue. For a discussion on such terminologies and their differences, see Andreas Winkelmann, this issue. The literature on restitution or repatriation is broad. For further examples, see the special section on 'Ritual Repatriation' in Museum Worlds 5 (2017): https://www. berghahnjournals.com/view/journals/museum-worlds/5/1/museum-worlds.5.issue-1. xml, accessed 18 June 2019; for the German context, the forum on 'Human Remains in Museums and Collections. A Critical Engagement with the "Recommendations" of the German Museums Association (2013),' 3 February 2017, https://www.hsozkult.de/debate/id/ diskussionen-3909, accessed 18 June 2019; and 'Guidelines for German Museums. Care of Collections from Colonial Contexts' of the German Museum Association: https://www. museumsbund.de/wp-content/uploads/2019/09/dmb-guidelines-colonial-context-2019. pdf, accessed 6 February 2020; for the French context, the report on 'The Restitution of African Cultural Heritage: Toward a New Relational Ethics' published by Felwine Sarr and Bénédicte Savoy, November 2018, http://restitutionreport2018.com/, accessed 18 June 2019.

3 I pose these questions in the forthcoming book Refocusing Ethnographic Museums through Oceanic Lenses (University of Hawai'i Press) in the context of the historical restitution of iwi kūpuna (ancestral remains) from the State Ethnographic Collections Saxony, Germany, to Hawai'i, in October 2017. These questions also informed the subsequent international 
conference on 'Sensitive Heritage: Ethnographic Museums and Material/Immaterial Restitutions' held on 11-13 December 2018, at the Grassi Museum für Völkerkunde zu Leipzig, Germany, which formed the basis for developing this special issue.

4 The literature on heritage, feelings, emotions and affect is wide. Rather than reviewing this literature here, I refer to other publications that offer such reviews (Schorch 2014; Schorch et al. 2017).

5 For 'defensive discourses', see the call for papers for the conference on 'Restitution of Colonial Collections in Europe: Possibilities, Challenges, Dilemmas' on 2-3 December 2019 in Ghent, Belgium: http://www.tapas.ugent.be/activities/restitutionofcolonialcollectionsineurope/ callforpapers, accessed 18 February 2020.

\section{References}

Aranui, A. K. (2017) 'Māori on the Move: Should Museums Repatriate Their Dead?', Current World Archaeology, 7 (8) 12-3.

Bredekamp H. and Schuster P.-K. (eds) (2016) Das Humboldt Forum: Die Widergewinnung der Idee, Berlin: Wagenbach.

Fforde, C., Hubert J. and Turnbull, P. (eds) (2004) The Dead and Their Possessions: Repatriation in Principle, Policy and Practice, London \& New York: Routledge.

Förster, L., Edenheiser, I., Fründt, S. and Hartmann, H. (eds) (2018) Provenienzforschung zu ethnografischen Sammlungen der Kolonialzeit. Positionen in der aktuellen Debatte, Berlin: Humboldt-Universität https://edoc.hu-berlin.de/ handle/18452/19768.

Hakiwai, A. T. (2014) He Mana Taonga, he Mana Tangata: Māori Taonga and the Politics of Māori Tribal Identity and Development. Unpublished PhD Thesis: Victoria University of Wellington.

Jenkins, T. (2011) Contesting Human Remains in Museum Collections: The Crisis of Cultural Authority New York: Routledge.

Kreps, C. F. (2003) Liberating Culture: Cross-Cultural Perspectives on Museums, Curation and Heritage Preservation, London: Routledge.

Macdonald, S. (2008) Difficult heritage: Negotiating the Nazi Past in Nuremberg and Beyond, London \& New York: Routledge.

Marstine, J. (2011) The Routledge Companion to Museum Ethics: Redefining Ethics for the Twenty-First Century Museum, London \& New York: Routledge.

Phillips, R. B. (2013) Museum pieces: Toward the Indigenization of Canadian museums, Montreal and Kingston: McGill-Queen's University Press.

Redmond-Cooper, R. (ed) (2015) Heritage, Ancestry and Law: Principles, Policies and Practices in Dealing with Historical Human Remains, Builth Wells, UK: Institute of Art and Law Ltd.

Schorch, P. (2014) 'Cultural Feelings and the Making of Meaning', International Journal of Heritage Studies, 20 (1) 22-35. 
Schorch, P. and Kahanu, N. M. K. Y. (2015) 'Forum as Laboratory: The Cross-Cultural Infrastructure of Ethnographic Knowledge and Mmaterial Potentialities', in Stiftung Preußischer Kulturbesitz (eds) Prinzip Labor: Museumsexperimente im Humboldt Lab Dahlem, 241-8, Berlin: Nicolai.

Schorch, P. with Kahanu, N. M. K. Y., Mallon, S., Pakarati, C. M., Mulrooney, M., Tonga, N. and Tengan, T. P. K. (In Print) Refocusing Ethnographic Museums Through Oceanic Lenses, Honolulu: University of Hawai'i Press.

Schorch, P. and McCarthy, C. (eds) (2019) Curatopia: Museums and the Future of Curatorship, Manchester: Manchester University Press.

Schorch, P., McCarthy, C. \& Dürr, E. (2019) 'Introduction: Conceptualising Curatopia' in Philipp Schorch and Conal McCarthy (eds) Curatopia: Museums and the Future of Curatorship, 1-16, Manchester: Manchester University Press.

Schorch, P., Waterton, E. and Watson S. (2017) 'Museum Canopies and Aaffective Cosmopolitanism: Cultivating Cross-Cultural Landscapes for Eethical Embodied Responses', in Divya Tolia-Kelly, Emma Waterton \& Steve. Watson (eds) Heritage, Affect and Emotion: Politics, Practices and Infrastructures, 93-113, London \& New York: Routledge.

Silverman, R. (ed) (2014) Museum as process: Translating Local and Global Knowledges, London \& New York: Routledge.

Stanley. N. (ed) (2007) The future of indigenous museums: Perspectives from the Southwest Pacific, Oxford \& New York: Berghahn Books.

Stiftung Preußischer Kulturbesitz (eds) (2015) The Laboratory Concept: Museum Experiments in the Humboldt Lab Dahlem. Berlin: Nicolai.

Thiemeyer, T. (2016). 'Deutschland Postkolonial: Ethnologische und Genealogische Erinnerungskultur', Merkur: Deutsche Zeitschrift für Europäisches Denken, 70 3345.

Turnbull, P. and Pickering, M. (eds) (2010) The Long Way Home: The Meanings and Value of Repatriation, Oxford \& New York: Berghahn.

Tythacott, L. and Arvanitis, K. (eds) (2014) Museums and Restitution: New Practices, New Approaches, Farnham: Ashgate.

von Bose, F. (2016) Das Humboldt-Forum: Eine Ethnografie Seiner Planung, Berlin: Kulturverlag Kadmos.

\section{Biography}

Philipp Schorch is Professor of Museum Anthropology at Ludwig-Maximilians-Universität in Munich, Germany, where he leads an ERC-funded research project entitled 'Indigeneities in the $21^{\text {st }}$ Century'. He is also an Honorary Senior Research Associate at the Museum of Archaeology and Anthropology at the University of Cambridge, UK. Philipp's research focuses on museums, material culture/history/theory, contemporary art and (post-)colonial histories, the Pacific and Europe, collaborations with Indigenous artists/curators/scholars, and (post-) socialist environments. He is lead co-author of Refocusing Ethnographic Museums through Oceanic Lenses (University of Hawai'i Press, in print), and co-editor of Exploring Materiality and Connectivity in Anthropology and Beyond (UCL Press, in print) and Curatopia: Museums and the Future of Curatorship (Manchester University Press, 2019). 